\title{
Review of the Survey's activities in 1985
}

\section{Martin Ghisler}

Director

The systematic investigation of the geology of Greenland for the State was continued in 1985 by the Geological Survey of Greenland (GGU). The investigations encompassed basic research and geological mapping as well as investigations in applied disciplines. Field work, mainly in the months of June, July and August, was carried out by seventy-five scientists and technicians, half of whom belong to the Survey's staff. In addition to the GGU parties several groups from other institutions worked in close collaboration with GGU. The areas of field activity reported on in 1985 are indicated on fig. 1.

During 1985 the Survey was partly reorganised, and it is now built up of six main units: Department of Stratigraphy and Structural Geology, Department of Precambrian Geology, Department of Geochemistry, Department of Mineral Resources, Department of Petroleum Geology and Department of Glaciology and Glacial Geology. The administration, computing facilities and editorial staff are directly responsible to the Director.

\section{North Greenland}

The North Greenland expedition was again, as in 1984, the Survey's main field activity with 40 participants. It was the last year of a five-years project, which covered the eastern part of North Greenland in 1978-80, and the central and western part of North Greenland in 1984-85. The systematic geological investigations in 1985 included 1:500 000 geological mapping, sampling of stream sediments, geochemical mapping, palaeomagnetic studies as well as petroleum source rock investigations based on a shallow core-drilling programme. The last named was funded by the Danish Ministry of Energy.

\section{West and South Greenland}

GGU continued glaciological and hydrological work as part of the hydropower development programme. Data were collected continuously at GGU's two stations east of Nuuk/Godthåb and south of Søndre Strømfjord from early June to the beginning of September. Additional work was done near the Sukkertoppen Ice Cap and along the ice margin north of Jakobshavn. At the latter location radar sounding and magnetic methods were successfully applied to mapping of the subglacial topography. 


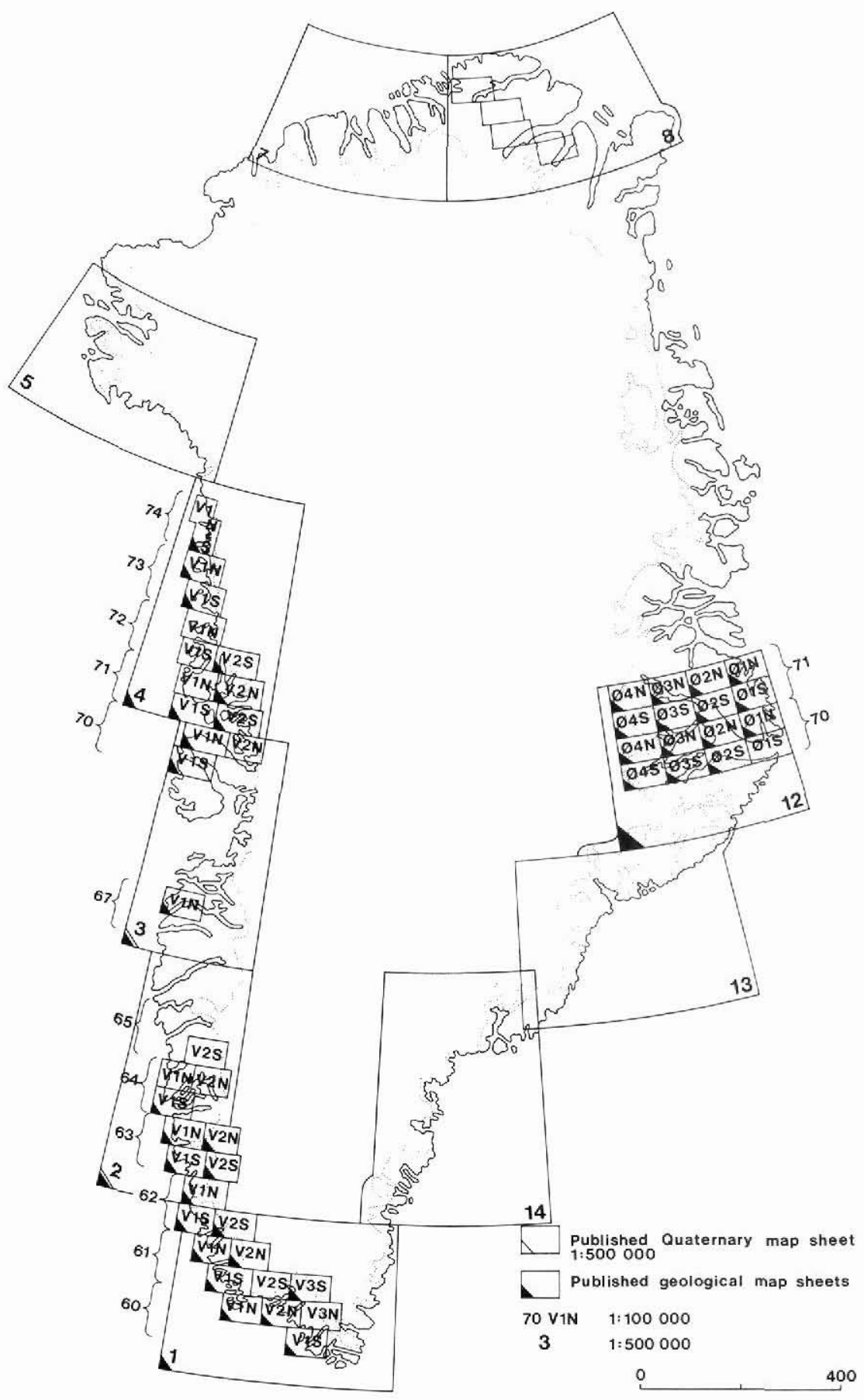

Fig. 2. Map sheets published and in preparation by the Survey (see inside rear cover). 
The Tertiary lavas were investigated in detail at different localities on Disko and Nûgssuaq, including sampling of migrated hydrocarbons at the latter site. An EECsupported study of the phosphate potential of a carbonatite complex near Sukkertoppen was completed.

The geological mapping (scale 1:100 000) of the Fiskefjord sheet (64 V. $1 \mathrm{~N}$ ) was continued, with field work in 1985 along the outer Godthåbsfjord.

A reconnaissance stream-sediment survey (heavy minerals) in the area between Godthåb and Frederikshåb Isblink revealed many scheelite anomalies. The tungsten province of West Greenland connected with Archaean supracrustals was thus extended and now covers a region of about $120 \times 300 \mathrm{~km}$. Detailed studies and mapping of stratabound tungsten mineralisation were carried out in the vicinity of Nuuk/Godthåb.

In South Greenland the field work of the EEC-supported project on the pyrochlore mineralisation connected with syenites around Motzfeldt $\$ \varnothing$, was completed. The uranium exploration programme, financed by the Danish Ministry of Energy, was continued with laboratory studies based mainly on field work in 1984.

Aeromagnetic measurements, essentially covering the central part of the Inland Ice south of $66^{\circ} \mathrm{N}$, were continued in co-operation with the Geological Survey of Canada and the National Aeronautical Establishment of Canada.

\section{East Greenland}

A systematic regional geological investigation and 1:500 000 mapping programme is planned for South-East Greenland in the summers of 1986 and 1987. In 1985 the necessary fuel depots and other logistic facilities were established.

Petroleum geological investigations were continued in Jameson Land and Traill $\emptyset$, mainly concentrated on sampling for source rock analyses and followed by a short reconnaissance to Wollaston Forland.

\section{General}

Studies on the heavy metal content $(\mathrm{Hg}, \mathrm{Cd}, \mathrm{Pb})$ of sea water and bottom sediments were carried out in co-operation with the Greenland Fisheries and Environmental Research Institute. Samples were collected around the lead-zinc mine at Maarmorilik, near the closed lead-zinc mine at Mestersvig, around the cryolite mine at Ivittuut and along the coast of East Greenland from Ella $\emptyset$ to Kap Farvel.

GGU assisted the Mineral Resources Administration with inspection of mineral exploration and exploitation activities in Jameson Land, East Greenland, where ARCO established a base camp at Constable Pynt in Hurry Inlet in the summer of 1985 and started geophysical exploration in November. GGU is responsible for the inspection of the geological/geophysical part of the exploration programme and followed in the field the start of seismic operations including evaluation of a test seis- 
mic survey. The activities of Greenex A/S at Maarmorilik, Disko-Nûgssuaq and Târtoq were inspected. GGU geologists visited the Godthåb area, where Kidd Creek Ltd. was carrying out an exploration programme, and the Kryolitselskabet Øresund activities around Ivittuut. Assistance was also provided to the Mineral Resources Administration in the geological evaluation of private company reports and applications for concessions.

During the year four new geological map sheets at a scale of 1:100 000 were printed, as well as one in the 1:500 000 geological series (fig. 2). Five Survey Reports and four Bulletins were published. As a result of GGU activities some thirty contributions appeared in 1985 in international scientific journals. 